\title{
Yliopisto-opettajan järki ja tunteet
}

Sanna Kivimäki, Merja Kinnunen \& Olli Löytty (toim. 2006).

Tilanteen taju. Opettaminen yliopistossa. Vastapaino, 207 sivua.

Yliopisto-opettajatkin ovat oikeita ihmisiä! Suuren yleisön edessä tieteellisen viileästi luennoiva opettaja ei välttämättä olekaan niin itsevarma, kuin miltä hän saattaa vaikuttaa. Asiantuntijan työhönkin kuuluu tunnemylläkkkää - intoa, itsevarmuutta, epäröintiä, jännittämistä, kiukkua. Opettaminen näyttää opettajien kokemusten näkökulmasta kovin toisenlaiselta, kuin asiantuntija- ja professioretoriikka antaa ymmärtää.

Kirjan kirjoittajakunta koostuu eri tieteenalojen yliopistoopettajista. Heitä yhdistää työskentely monitulkintaisissa inmistieteissä, joissa "oikeita tai vääriä tulkintoja on vaikea määritellä niin tutkimuksessa kuin opetuksessakin". Kirja on varsinainen runsauden sarvi. Siinä on kolme osaa: tila, oma ja käytännöt. Lukuja on 24, kirjoittajia 32. Joukkoon mahtuu aloittelevien ja kokeneiden opettajien lisäksi muutamia opiskelijoitakin.

Kirjoittajien ammattiasemien jakauma suhteessa yliopiston henkilöstö- ja sukupuolirakenteeseen on ilmeisen harkittu. Kirjoittajajoukko on naisvaltainen kuten yliopiston opettajakuntakin: naisia on 21 ja miehiä 11. Viidestä professorikirjoittajasta naisia on kaksi. Tosin naisten enemmistöä saattaa selittää sekin, että miehet eivät välttämättä hevin lähde kirjoittamaan kokemuksistaan, vaan haluavat säilyttää itsevarman tiedemiehen kasvonsa.
Ensimmäisessä osassa keskitytään tilaan, jossa tekstit sijoittavat opettamisen yliopistoinstituution muutoksiin ja yhteiskunnallisen vallan prosesseihin. Ne pureutuvat siihen, mitä ovat hyvän opettamisen ehdot ja vaatimukset nykyisessä "uuden kapitalismin ajan yliopistossa". Tähän tematiikkaan nivoutuu myös Leena Eräsaaren artikkeli yliopiston tiloista - arkkitehtuuri ja tilojen käyttö eivät jää erilleen tehostamispyrkimyksistä. Yhdenmukaistuvissa yliopistorakennuksissa suositaan avokonttoreita, siirrettäviä seiniä, läpinäkyvyyttä ja lasia, jolla luento- ja seminaaritilojen lisäksi yksityiset tilat kuten työhuoneet ja kirjastot muutetaan näyttämöiksi, joissa toimivia voidaan valvoa.

\section{Uutta ja vanhaa konjakkia}

Suomen nuoren, vasta 1960-luvulla voimakkaaseen laajenemiseen lähteneen yliopistolaitoksen on 1990-luvulta lähtien saavuttanut taloudellisen kasvun ja globaalissa kilpailussa menestymisen pakko. Yliopistojenkin tulee olla tehokkaita, tuloksellisia ja vaikuttavia. $\mathrm{Ne}$ on muutettu yritysyliopistoiksi, joiden toimintatapa ja johtaminen muistuttavat entistä enemmän yksityisen sektorin käytäntöjä.

Kirjoittajien kriittisiä pohdintoja yliopistolaitoksen muutoksesta sävyttää haikailu entisen sivistysyliopiston perään.
Virpi Hämeen-Anttila tosin arvioi, ettei Suomessa ole sivistysyliopistoon päästykään. Suomalainen yliopistokulttuuri on kuin uutta konjakkia verrattuna pitkän sivistysyliopistokulttuurin omaaviin maihin - ne edustavat sitä vanhaa konjakkia.

Muutostilanteessa yliopistoopettajat toimivat perinteisten akateemisten ja uuden julkishallinnon managerialististen arvojen välillä. Oili-Helena Ylijoen ja Johanna Hakalan mukaan tilanne on hankala, kun ei tiedä, kumpiin pelisääntöhin olisi viisasta nojautua. Monet opettajat tukeutuvat edelleen akateemisiin arvoihin ja ideaaleihin, joita ovat vapaus, sivistys, uuden etsiminen ja arvostuksen saavuttaminen tiedeyhteisössä. Toisaalta menestyksen eväitä haetaan laajojen verkostojen luomisesta, tuloksen tekemisestäjaarvostuksen saamisesta rahoittajien silmissä. Valitseepa aloitteleva tutkija kumman tahansa, molemmissa vaihtoehdoissa opetus jää tutkimukseen nähden sivuosaan.

Opettamisen hierarkia on myös sukupuolihierarkiaa, kuten Merja Kinnusen samoin kuin Ylijoen ja Hakalan artikkeleissa tuodaan esiin. Naisten osuus on professoreista 21 prosenttia, yliassistenteista 37, lehtoreista 54 , assistenteista $50 \mathrm{ja}$ tuntiopettajista 66 prosenttia. Kinnusen mukaan opetukseen on muotoutumassa uudenlaista sukupuolihierarkiaa, kun professorien ensisijainen opetusvastuu on siirtymässä jatkoopiskelijoihin, ja perusopetuksesta kantaa vastuun alempi 
opettaja- ja tutkijakunta, jotka ovat valtaosin naisia. Kuten Kinnunen toteaa, tämäntyyppinen jako muistuttaa eroa yläkoulun arvostetun miesopettajan ja alakoulun avustavan naisopettajan kesken.

\section{Dialogiin pitäisi päästä}

Kaksi muuta lukua keskittyvät opetuskokemuksiin ja käytännön opetustilanteiden virittämiin pohdintoihin. Kokemuksistaan kertoo 20 luvussa yhteensä 27 kirjoittajaa.

Silmiin pistävää on opetustapojen opettajakeskeisyys. Suosikkiaiheena puheenvuoroissa on yliopiston perinteinen opetusmuoto, luento.

Monet opetustilanteiden suunnittelun ja toteutuksen kuvaukset kerrotaan hauskasti ja tarinaa itseironialla höystäen. Esimerkiksi Mikko Lahtinen artikkeli "Kuuleeko Pori?" kertoo värikkäästi opetusteknologian tuomista rajoista opetuksen elävyydelle ja opettajan toiminnalle. Videoluennon laitepaljous sai luennoitsijan kangistumaan paikalleen, jolloin ajatus inspiroivasta luennosta ja ääneen ajattelusta muuttuikin neljän tunnin yksinpuheluksi. Ajatus jatkoluennoista saattoi luennoijan pakokauhun partaalle. Lopulta hän päätti luopua "turhista sivistysyliopistokotkotuksista", dialogeista, demonstraatioista ja reaaliaikaisista ajatusprosesseista. Lahtisen mukaan ne elävät luentojen aiheistoissa, mutta eivät itse toiminnassa, jossa tuon aiheiston sisältöjä siirretään opiskelijoille.

Esa Sironen kuitenkin painottaa luentoa opetusmuotona puolustavassa kirjan päätösluvussaan, että tärkeintä luennos- sa ei ole se, mitä opetetaan, vaan miten opetetaan. Säilymiskykyisin on tieteellinen asenne.

Tekstien yhteistä juonnetta etsiessäni totesin, että opetuksellisesta lähestymistavasta huolimatta moni opettaja pohtii opetuksen dialogisuutta. Asiantuntijallekaan ei riitä, että hän itse hallitsee opettamansa asiat. Haasteena on saada opiskelijat kiinnostumaan, ymmärtämään ja oppimaan ne.

Vesa Heikkisen kuvaus tekstintulkinnan opettamisesta avoimessa yliopistossa on lennokasta. Sanan opettaminen merkityksen purkamisesta alkavat hänen aikeensa päästä "sokraattiseen dialogiin", ilmapiiriin, jossa kenenkään eri tarvitsisi niellä mitään pureksimatta. Tavoite oli virittää opettajakeskeisellä puheleskelulla ilman kalvoja tai powerpointeja opiskelijat keskustelemaan tai jopa väittelemään. Vaan toisin kävi. Opetuksesta tuli opettajan monologia. Opiskelijoiden kiinnostus kohdistui ennen muuta tenttin tuleviin kysymyksiin. Opettajaa eniten havahduttaneessa kurssipalautteessa luki, että opetus oli ollut perinteistäkin perinteisempää.

Monelle muullekin opiskelijat ovat arvaamaton joukko. Minna Nikunen kuvaa opettajan uransa alkua: "Varustauduin ensimmäiselle luennolleni muutamalla kalvolla, keräsin rohkeuteni ja astuin leijonien eteen." Neljänkymmenen hengen ryhmän eteen astumisessa tukena oli luentosarjan koordinaattorin lisäksi harmaa hyvin leikattu bleiseri ja vesilasi, josta saattoi voidella jännityksestä käheytyvää kurkkuaan. Epävarmuuden tunteet nousevat esiin paitsi luennoilla, myös seminaarikeskustelujen vetämi- sessä. Kirsti Lempiäinen pohtii ahdistavuuden tunnetta, kun seminaarissa ei synny keskustelua. Tavatonta ei ole sekään, että osallistujat puhuvat toistensa ohi: dialogin sijaan syntyykin kilpailua, kuka osaa hienoimmin esittää asiansa. Lempiäisen mukaan yhteisölliseen oppimiseen ja opettamiseen on kuitenkin tärkeä pyrkiä, sillä ne ovat antiteeseja individualistiselle kulttuurille. Dialogisen opetuksen vaikeudet eivät koskeneet vain opettajia, vaan ne kohdattiin myös opiskelijoiden lukupiireissä.

Yliopisto-opettamiseen liittyy kertomusten perusteella valtava tunteiden kirjo. Kirjan ansiona pidän tunteiden merkityksen ja voiman esiin nostamista, sillä yleensä ne suljetaan järkikeskeisen koulutus- ja tiedekulttuurin ulkopuolelle. Eeva Jokinen luonnehtii yliopistoa instituutioksi, joka pysyy kasassa pelon voimalla. Opettajat pelkäävät epätäydellisyytensä paljastumista ja opiskelijat nolaamista. Kaikki pelkäävät olevansa tyhmiä. Jokisen tuntemukset luennoinnista herättävät kiinnostuksen vertailla miesten ja naisten asennoitumista siihen.

\section{Opetusta lukkarin metodilla}

Kasvatustieteilijän näkökulmasta kirjan lukukokemus on mielenkiintoinen, sillä kasvatustieteilijöitä ei kirjoittajista juuri löydy. Ehkäpä siitä syystä teksteissä ei juurikaan puhuta konstruktivismista tai toistella kasvatustieteen opettajadiskurssiin kuuluvia ydinlauseita hyvästä opettajasta, jolla oppisisällön hallinnan lisäksi on "oikealle" opettajalle kuuluva 
aito kiinnostus työhönsä. Kirjan kiinnostavinta antia ovat opettamista koskevat ajattelutavat ja kokemukset, kurkistus yliopisto-opetuksen kulisseihin eri tieteenaloilla. Teos tuo lisän narratiiviseen opettajatutkimukseen, jossa yliopisto-opetusta ei ole toistaiseksi juurikaan käsitelty.

Pedagogiikka näyttäytyy teksteissä aika merkillisessä valossa. Useimmat kirjoittajat ei- vät mainitse sitä lainkaan. Joillekin se on lisärasite, lähes kirosanan vastine. Teksteistä kuvastuu halu pitää edelleen kiinni siitä, että yliopiston opettajia ei muiden kouluasteiden opettajien tavoin velvoiteta pedagogisen pätevyyden hankkimiseen.

Kokemukset pedagogisesta koulutuksesta eivät liioin ole kasvatustieteen näkökulmasta erityisen mairittelevia. Mutta jos Virpi Hämeen-Anttilan näkemykseen on uskominen, yliopisto-opettajien pedagogisten valmiuksien kehittäminen olisi paikallaan. Hän väittää, että käytössä on edelleen lukkarin metodi eli yliopisto-opettajat opettavat samaan tapaan, kuten heitäitseään on opetettu. Tämän havainnon kirjan teksteistä voi lukijakin tehdä.

Marjo Vuorikoski 